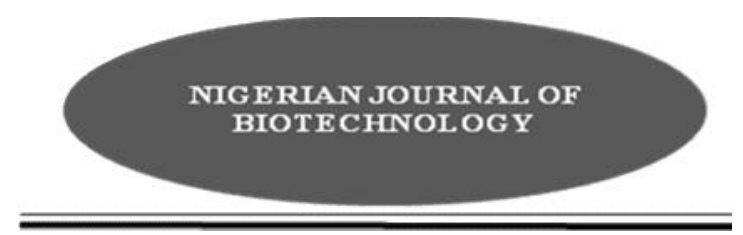

\title{
Response of African Catfish, Clarias gariepinus; (Burchell, 1822) to Diets of African Yam Bean, Sphenostylis stenocarpa Subjected to Two Processing Methods
}

\author{
Ogunji, J. O. ${ }^{1}$, Ozibo. J. ${ }^{1}$, Osai, A. ${ }^{1}$ and Ochang, S. ${ }^{1,2}$ \\ ${ }^{1}$ Department of Fisheries and Aquaculture, Ebonyi State University P.M.B. 053, Abakaliki Nigeria, \\ ${ }^{2}$ Department of Fisheries and Aquatic Science, Cross River University of Technology Calabar, Nigeria
}

(Received: 14:03:2016; Accepted: 04:07:2016)

\begin{abstract}
Response of Clarias gariepinus to diets of African yam bean (Sphenostylis stenocarpa) (AYB) subjected to two processing methods was assessed. Mature AYB was boiled, fermented and processed into meals. Seven diets were formulated to contain $44.07 \pm 0.48 \%$ crude protein and $19.03 \pm 0.05 \mathrm{~kJ} \mathrm{~g}^{-1}$ gross energy respectively. Fishmeal in the diets was substituted with each of the two processed AYB meals at $40 \%, 45 \%$ and $50 \%$ levels. Nine fingerlings (initial average weight $1.36 \pm 0.02 \mathrm{~g}$ ) were stocked per experimental tank. Experimental diets were fed to triplicate groups of catfish fingerlings at $\mathbf{1 0 \%}$ body weight for $\mathbf{5 6}$ days. Results showed that specific growth rate (SGR) and protein production value (PPV) were highest at $45 \%$ replacement of fermented AYB $(3.32 \pm 0.20 ; 49.30 \pm 17.94)$ compared to control $(3.17 \pm 0.44$; 38.89 \pm 12.49 ). Mean values for haematological parameters (PCV, HB, WBC and RBC) significantly increased $(P<0.05)$ above the initial status and control group. Haematological values for fish fed $40 \%$ inclusion level of fermented and boiled AYB were the highest. This study shows that AYB processed by fermentation and boiling were effective in enhancing fish growth. However, based on SGR and PPV results Fermented AYB should not be used in Clarias gariepinus diets beyond $45 \%$ inclusion level.
\end{abstract}

Key Words: African Catfish, Alternative Protein Sources, African Yam Beans, Haematology

Correspondence: ogunjijo@yahoo.com

\section{Introduction}

Thorarinsdottir et al. (2011) indicated that the aquaculture industry is the fastest growing food production industry in the world and approximately $50 \%$ of all fish consumed by humans is from aquaculture. They however observed that the costliest factor in the aquaculture production process is that of feed. Corroborating this fact Ogunji et al. (2008a) reported that the high prices of fishmeal in world markets have necessitated the search for another protein sources. According to Tacon and Metian (2008) fishmeal has been adjudged the most important and expensive protein ingredient used in aquafeeds. Fishmeal has been replaced with cheap plant proteins (Jackson et al., 1982; Tacon and Jackson, 1985; Webster et al., 1992; Ogunji and Wirth, 2001). One of the major local feed stuffs that meet the protein needs of most species is soybean meal (Ogunji, 2004). This feed ingredient has also become relatively expensive on account of its competitive value in fish and livestock feeds and as well as in human nutrition.

African yam bean (AYB) is one of the tropical legume seeds that have been scarcely used in fish feed production in spite of its relatively high crude protein content. The plant is found growing wild throughout tropical Africa, and most commonly in central and western Africa, especially in southern Nigeria. It is also reported to be cultivated in Ivory Coast, Ghana, Togo, Gabon, Congo, Ethiopia and parts of East Africa(Ref?). The African yam bean (AYB) has attracted research interest due to its nutrient content. Amino acid analysis indicates that lysine and methionine levels in the protein are equal to or better than those of soybeans (Obatolu et al., 2001).

However, like other legume beans, its nutritive value is masked by the occurrence of antinutritional factors (ANFs) such as alkaloids, 
flavonoids and saponins (Asuzu and Undie, 1986). ANFs are known to have negative effects on fish growth and general physiology. As such, the removal of ANFs using different processing methods is important to reduce the concentration of those factors (Ogunji et al., 2008b). This strengthens the position of Uwaegbute et al. (2012) that quality of foodstuffs may be improved by processing. The objective of this study therefore, was to determine the effect( of feed produced by using AYB processed by boiling and fermentation) on the growth performance and haematology of the African catfish, Clarias gariepinus.

\section{Materials and Methods}

The experiment was carried out at the Department of Fisheries and Aquaculture, Ebonyi State University, Abakaliki Nigeria. Mature African yam bean was purchased from a local farmer. The yam bean was visually inspected and defective ones discarded. The yam bean was subjected to two processing methods: Boiling and Fermentation respectively to detoxify antinutrient present. The method described by Obatolu et al. (2001) was used.

Experimental Diets: Fish meal and African yam bean meal were used as the major dietary protein sources in the diets. Seven diets were formulated to contain $44.07 \pm 0.48 \%$ crude protein (Mean \pm SD) and $19.03 \pm 0.05 \mathrm{~kJ} \mathrm{~g}^{-1}$ gross energy (Mean \pm SD) respectively (Table 1 ).

Table 1: Composition of fermented and boiled experimental diets fed Clarias gariepinus

\begin{tabular}{llllllll}
\hline Ingredients & FD1 & FD2 & FD3 & BD1 & BD2 & BD3 & Control \\
\hline Fishmeal & 34 & 33 & 32 & 34 & 33 & 32 & 41 \\
African Yam Bean & 40 & 45 & 50 & 40 & 45 & 50 & 0 \\
Maize & 9.5 & 5.5 & 1.5 & 9.5 & 5.5 & 1.5 & 42.5 \\
Soy Bean & 15 & 15 & 15 & 15 & 15 & 15 & 15 \\
Mineral/Vitamin ${ }^{1}$ Mix & 1 & 1 & 1 & 1 & 1 & 1 & 1 \\
Cod-liver Oil $_{\text {Total }}^{0.5}$ & 0.5 & 0.5 & 0.5 & 0.5 & 0.5 & 0.5 \\
\hline
\end{tabular}

$\mathrm{F}=$ fermented; $\mathrm{B}=$ boiled

${ }^{1}$ Min/vitamin premix: Vit. A., 15,000,000 iu; Vit B., 4,400,000 iu; Vit. E., 2500 iu; Vit. K., 4,350 mg; Vit. B2, 4,350 mg; Vit. B6, 2,350 mg; Vit. B12, 11,350 mcg; Vit. C, 1,000 mg; Nicotinamide, 16,700mg; Calcium Pantothenate, 87,000 mg; Sodium Sulphate, 50,000 mg; Magnesium Sulphate, 12,000 mg; Copper sulphate, 12,000 mg; Zinc Sulphate, 12,000 mg; Managanese Sulphate, 12,000 mg; Excipients Q.S., 1,000 mg.

Fishmeal in the diets was substituted with each of the two processed AYB meals (Fermented - F; Boiled - B) at 40\%, 45\% and $50 \%$ levels. Control diet did not contain AYB (Table 1). The dry diet component including vitamin $\mathrm{C}$ and oil were thoroughly mixed. Water was added and the feed was pressed into pellets of $2 \mathrm{~mm}$ diameter. Locally fabricated machine was used to pellet the feed. The pelleted feed was sun dried to reduce moisture content. This was done to enhance quality and was stored in refrigerator until use (Ogunji et al., 2008b).

Experimental fish: A total of 189 catfishes (initial average weight $1.4 \pm 0.0 \mathrm{~g}$ ) were acclimatized for seven days. They were weighed and distributed among 21 experimental tanks at a rate of nine fish per aquarium tank with 10 litres of water. Test diets were randomly assigned using completely randomized design to triplicate tanks. The fish were fed a restricted ration of $10 \%$ body weight per day in two portions for 56 days in static water. Quantity of feed was adjusted forth nightly after batch-weighing of experimental fish. The aquaria were cleaned and water completely replaced by siphoning every other day to avoid fouling. Water temperature, dissolved oxygen, nitrate and $\mathrm{pH}$ were monitored. Temperature was maintained at $28 \pm$ $0.2{ }^{\circ} \mathrm{C}$, dissolved oxygen between $7.6 \pm 0.9 \mathrm{mg} \mathrm{L}^{-}$ 1 , nitrate $0.00 \mathrm{mg} \mathrm{L}^{-1}$ and $\mathrm{pH}$ between $7.6 \pm 0.7$. No critical values were detected in any of the tanks. Feedstuffs were analyzed prior to diet formulation, while analysis of experimental data and samples of fish were carried out at the end of experiment.

Striking time was determined by noting the time it took the first fish to pick feed particle (Eyo and Ezechie, 2004). This was assessed to know the degree of acceptability of the experimental diets by fish. Striking time (1/time) was calculated according to (Sogbesan and Ugwumba 2006). 
Biochemical and haematological analysis: Blood samples were collected at the commencement, and at the end of the experiment from the caudal vein into an EDTA litium tubes. The blood was analyzed to determine the packed cell value (PCV) with microhaematocrit using heparnized capillary tube (25mm). Red blood cell (RBC) and white blood cell (WBC) counts were determined as described by Blaxhal and Diasley (1973). Hemoglobin (Hb) concentration was determined by the methods described by Wedemeyer and Yasutake (1977).

The amino acid and proximate analyses of feed stuff and feed samples were carried out. Amino acid in samples was determined spectorophotometrically using ninhydrin chemical reaction (Schroeder et al., 1990). Protein ( $\mathrm{N} \mathrm{x}$ 6.25) was determined by the Kjeltec System (Tecator) and crude fat by Soxtec System HT (Tecator) using petroleum ether. Ash was determined by burning in a muffle furnace at $550^{\circ} \mathrm{C}$ for 10 hours. Gross energy was calculated using the following factors: crude protein $=23.9$ $\mathrm{kJ} \mathrm{g}^{-1}$, crude lipids $=39.8 \mathrm{~kJ} \mathrm{~g}^{-1}$ and NFE $=17.6$ kJ $\mathrm{g}^{-1}$ (Schulz et al. 2005).

Statistical and growth analysis: At the end of the experiment, all the fish was weighed and data obtained from triplicate tanks were used to calculate weight gains, specific growth rate (SGR) and percentage body weight. Weight gain $=$ final weight - initial weight, SGR $=\left(\mathrm{LnW}_{2}\right.$ - $\left.\mathrm{LnW}_{1}\right) /\left(\mathrm{T}_{2}-\mathrm{T}_{1}\right) 100$ where $\mathrm{W}_{1}$ and $W_{2}=$ initial and final weight of fish and $T_{1}$ and $T_{2}=$ time in days.

Percentage body weight (\% BW or PBWG $(-\%)=$ $\left(W_{2}-W_{1} / T_{2}-T_{1}\right) \times 100 ;$ Where: $W_{2}=$ final

weight of fish, $W_{1}=$ initial weight of fish and $\left(T_{2}-\right.$ $\left.\mathrm{T}_{1}\right)=$ time (day).

Nitrogen retention efficiency (NRE) (Singh et al., 2011) or Protein production value (PPV) (Slawiski et al., 2013) is the nitrogen deposition with respect to ingested nitrogen. This variable was calculated for each treatment from the initial nitrogen content of the fish as stocked and the final nitrogen content of fish in each treatment. It was calculated as follows: 100 $\times$ [ crude protein final fish $\times$ biomass final tank weight) - (crude protein initial fish $\times$ biomass initial tank weight)] / (crude protein diet $x$ total feed intake)

All growth and heamatological data were subjected to one way analysis of variance
(ANOVA). The significance of difference between means was determined by Duncan's Multiple Range test $(p<0.05)$ using SPSS for windows (version 17). Values were expressed as means \pm SE.

\section{Result}

The proximate and amino acid composition of feed stuffs and experimental diets are presented on Tables 2, 3, 4 and 5. Results of the amino acid showed that processing AYB by fermentation increased amino acid values while boiling process decreased the content. Similar observation was made in the proximate analysis in comparison with raw AYB.

The growth response of $C$. gariepinus fed boiled and fermented African yam bean meals at varying levels of dietary incorporation is shown in (Table 6). With respect to the values of PPV and SGR best growth response was obtained at $45 \%$ inclusion levels of fermented yam bean meal. SGR values were not significantly different from fish fed control diet and BD2 (Boiled Diet 2). PPV values were not significantly different in all the groups. Values of fish fed FD3 (50\% inclusion) were the lowest for SGR and PPV.

The results of analysis of Clarias gariepinus (whole fish) fed fermented and boiled African yam bean are presented in Table 7 . The protein content of fish fed boiled African yam bean (BAYB) meal at $45 \%$ inclusion was significantly $(P<0.05)$ higher than all other feeding groups. Fish fed control diet accumulated less body protein. The protein content of the carcass of fish fed BAYB meal at $50 \%$ inclusion did not differ from the initial carcass but differed from all other feeding group. Protein contents of fish fed FAYB meal at $40 \%$ and $45 \%$ inclusion levels were not different but differed from other feeding groups. Fat content of all the different feeding groups were significantly different from one another. Fish fed diet with $45 \%$ BAYB meal inclusion accumulated the highest fat content. The energy content of all the feeding group were not significantly different from one another and from the control.

Table 8 shows the mean value and standard error (SE) of all blood parameters for each feeding group. The blood indices in each treatment varied significantly $(P<0.05)$ and were higher than control and initial. Among the treatment groups, PCV, $\mathrm{Hb}, \mathrm{WBC}$ and $\mathrm{RBC}$ content of fish fed fermented diet, at $40 \%$ inclusion (FD1) was significantly higher $(P<0.05)$. 
Table 2: The proximate composition (\%) of feed ingredients.

\begin{tabular}{lllllll}
\hline & FAYB & BAYB & MAIZE & SOYBEAN & FISH MEAL & RAW AYB \\
\hline Dry matter & $90.06 \pm 0.01$ & $85.27 \pm 0.01$ & $91.72 \pm 0.01$ & $90.84 \pm 0.01$ & $93.65 \pm 0.01$ & $91.13 \pm 0.01$ \\
Crude protein & $23.14 \pm 0.02^{\mathrm{d}}$ & $20.78 \pm 0.02^{\mathrm{b}}$ & $10.91 \pm 0.03^{\mathrm{a}}$ & $46.43 \pm 0.05^{\mathrm{e}}$ & $67.83 \pm 0.02^{\mathrm{f}}$ & $22.31 \pm 0.04^{\mathrm{c}}$ \\
Crude fat & $6.59 \pm 0.01^{\mathrm{f}}$ & $4.66 \pm 0.01^{\mathrm{b}}$ & $3.93 \pm 0.01^{\mathrm{a}}$ & $5.05 \pm 0.01^{\mathrm{d}}$ & $6.39 \pm 0.01^{\mathrm{e}}$ & $4.85 \pm 0.01^{\mathrm{c}}$ \\
Fibre & $2.28 \pm 0.01^{\mathrm{c}}$ & $4.96 \pm 0.01^{\mathrm{e}}$ & $1.95 \pm 0.01^{\mathrm{b}}$ & $4.17 \pm 0.01^{\mathrm{d}}$ & $0.00 \pm 0.00^{\mathrm{a}}$ & $6.17 \pm 0.01^{\mathrm{f}}$ \\
Ash & $4.23 \pm 0.01^{\mathrm{c}}$ & $4.05 \pm 0.01^{\mathrm{b}}$ & $1.08 \pm 0.01^{\mathrm{a}}$ & $7.51 \pm 0.01^{\mathrm{e}}$ & $14.37 \pm 0.01^{\mathrm{f}}$ & $5.77 \pm 0.01^{\mathrm{d}}$ \\
NFE $^{2}$ & $66.01 \pm 0.02^{\mathrm{c}}$ & $70.52 \pm 0.03^{\mathrm{e}}$ & $84.03 \pm 0.02^{\mathrm{f}}$ & $41.02 \pm 0.08^{\mathrm{b}}$ & $11.42 \pm 0.02^{\mathrm{a}}$ & $67.07 \pm 0.06^{\mathrm{d}}$ \\
Energy $^{3}$ & $19.72 \pm 0.00^{\mathrm{d}}$ & $19.23 \pm 0.01^{\mathrm{c}}$ & $18.89 \pm 0.07^{\mathrm{a}}$ & $20.32 \pm 0.00^{\mathrm{e}}$ & $20.76 \pm 0.02^{\mathrm{f}}$ & $19.07 \pm 0.00^{\mathrm{b}}$ \\
\hline
\end{tabular}

1. Values are mean of duplicate determination $\pm \mathrm{SE}$;

2. NFE $=100-(\%$ protein $+\%$ fat $+\%$ ash $)$;

3. Calculated by: crude protein $=23.9 \mathrm{~kJ} \mathrm{~g}^{-1}$, crude lipids $=39.8 \mathrm{~kJ} \mathrm{~g}^{-1}$ and NFE $=17.6 \mathrm{~kJ} \mathrm{~g}^{-1}$ (Schulz et al. 2005).

Table 3: Proximate composition ( $\%$ dry matter) of experimental diets $^{1}(n=3)$

\begin{tabular}{llllllll}
\hline \multicolumn{3}{c}{ Fermented } & \multicolumn{3}{c}{ Boiled } & \multicolumn{2}{c}{ Control } \\
& $40 \%$ & $45 \%$ & $50 \%$ & $40 \%$ & $45 \%$ & $50 \%$ & $0 \%$ \\
\hline Dry matter & $92.84 \pm 0.01$ & $93.05 \pm 0.01$ & $92.91 \pm 0.01$ & $91.73 \pm 0.01$ & $91.67 \pm 0.01$ & $91.72 \pm 0.01$ & $93.54 \pm 0.01$ \\
Crude protein & $44.34 \pm 0.03$ & $44.63 \pm 0.03$ & $44.72 \pm 0.02$ & $43.62 \pm 0.02$ & $43.62 \pm 0.02$ & $43.72 \pm 0.04$ & $43.82 \pm 0.03$ \\
Crude fat & $4.55 \pm 0.01$ & $4.66 \pm 0.01$ & $4.61 \pm 0.01$ & $4.27 \pm 0.01$ & $4.33 \pm 0.01$ & $4.24 \pm 0.01$ & $4.40 \pm 0.01$ \\
Ash & $13.47 \pm 0.01$ & $13.39 \pm 0.01$ & $13.57 \pm 0.01$ & $12.85 \pm 0.01$ & $12.96 \pm 0.01$ & $13.06 \pm 0.01$ & $13.56 \pm 0.01$ \\
NFE & $37.64 \pm 0.01$ & $37.32 \pm 0.04$ & $37.10 \pm 0.02$ & $39.26 \pm 0.02$ & $39.19 \pm 0.03$ & $38.98 \pm 0.06$ & $38.23 \pm 0.04$ \\
Fibre & $3.37 \pm 0.01$ & $3.25 \pm 0.01$ & $3.30 \pm 0.01$ & $3.16 \pm 0.01$ & $3.22 \pm 0.01$ & $3.13 \pm .0 .01$ & $3.58 \pm 0.01$ \\
Energy $^{3}$ & $19.04 \pm 0.00$ & $19.09 \pm 0.00$ & $19.06 \pm 0.00$ & $19.04 \pm 0.00$ & $19.02 \pm 0.00$ & $18.99 \pm 0.00$ & $18.95 \pm 0.00$ \\
\hline
\end{tabular}

1. Values are mean of triplicate determination \pm standard error. 2. NFE $=100-(\%$ protein $+\%$ fat $+\%$ ash) 3. Gross energy $=$ crude protein $=23.9 \mathrm{~kJ} \mathrm{~g}^{-1}$, crude lipids $=39.8 \mathrm{~kJ} \mathrm{~g}^{-1}$ and NFE $=17.6 \mathrm{~kJ} \mathrm{~g}^{-1}$ (Schulz et al. 2005).

Table 4: Amino Acid Composition (\% Dry Matter) of Raw and Processed African Yam Beans (AYB) Samples ${ }^{1}$

\begin{tabular}{|c|c|c|c|}
\hline AMINO ACIDS & FERMENTED AYB & BOILED AYB & RAW AYB \\
\hline Alanine* & 1.88 & 1.26 & 1.67 \\
\hline Arginine* & 2.97 & 2.21 & 2.78 \\
\hline Aspartic Acid & 4.06 & 3.18 & 3.89 \\
\hline Cysteine & 0.61 & 0.37 & 0.53 \\
\hline Methionine * & 0.54 & 0.18 & 0.42 \\
\hline Glutamic Acid & 7.63 & 5.39 & 6.35 \\
\hline Glycine & 1.96 & 1.58 & 1.79 \\
\hline Histidine * & 1.67 & 1.36 & 1.51 \\
\hline Isoleucine * & 1.85 & 1.52 & 1.66 \\
\hline Leucine * & 3.13 & 2.24 & 2.98 \\
\hline Lysine * & 2.82 & 2.53 & 2.67 \\
\hline Phenylalanine * & 2.49 & 2.11 & 2.34 \\
\hline Proline & 2.23 & 1.96 & 2.09 \\
\hline Serine & 2.17 & 1.65 & 2.05 \\
\hline Threonine * & 1.57 & 1.18 & 1.39 \\
\hline Tryptophan * & 0.45 & 0.23 & 0.37 \\
\hline Tyrosine & 1.65 & 1.39 & 1.58 \\
\hline Valine * & 2.06 & 1.64 & 1.88 \\
\hline
\end{tabular}

*Essential Amino Acids. 'Values are mean of duplicate determinations $\pm \mathrm{SE}$. 
Table 5: Amino Acid Composition (\% Dry Matter) of Experimental Diets ${ }^{1}$

\begin{tabular}{llllllll}
\hline Amino Acids & FD1 & FD2 & FD3 & BD1 & BD2 & BD3 & CONTROL \\
\hline Alanine * & 1.26 & 1.28 & 1.31 & 1.17 & 1.21 & 1.24 & 1.19 \\
Arginine * & 1.37 & 1.39 & 1.34 & 1.29 & 1.33 & 1.31 & 1.27 \\
Aspartic Acid & 2.98 & 3.04 & 3.07 & 2.50 & 2.54 & 2.52 & 2.48 \\
Cysteine & 0.33 & 0.36 & 0.39 & 0.29 & 0.34 & 0.31 & 0.30 \\
Methionine * & 0.28 & 0.34 & 0.31 & 0.25 & 0.28 & 0.30 & 0.27 \\
Glutamic Acid & 5.28 & 5.32 & 5.30 & 5.02 & 4.97 & 5.07 & 5.06 \\
Glycine & 1.34 & 1.36 & 1.32 & 1.26 & 1.24 & 1.29 & 1.22 \\
Histidine * & 1.22 & 1.25 & 1.27 & 1.18 & 1.16 & 1.21 & 1.17 \\
Isoleucine * & 1.49 & 1.46 & 1.51 & 1.37 & 1.43 & 1.39 & 1.35 \\
Leucine* & 2.48 & 2.45 & 2.53 & 2.26 & 2.34 & 2.29 & 2.31 \\
Lysine * & 1.47 & 1.49 & 1.52 & 1.39 & 1.45 & 1.43 & 1.41 \\
Phenylalanine * & 1.36 & 1.38 & 1.34 & 1.23 & 1.27 & 1.25 & 1.21 \\
Proline & 1.79 & 1.83 & 1.81 & 1.59 & 1.61 & 1.55 & 1.57 \\
Serine & 1.68 & 1.70 & 1.70 & 1.51 & 1.48 & 1.51 & 1.46 \\
Threonine * & 1.18 & 1.21 & 1.21 & 1.05 & 1.03 & 1.07 & 1.01 \\
Tryptophan * & 0.23 & 0.27 & 0.25 & 0.15 & 0.13 & 0.17 & 0.13 \\
Tyrosine & 1.22 & 1.18 & 1.25 & 1.09 & 1.07 & 1.05 & 1.08 \\
Valine * & 1.57 & 1.64 & 1.61 & 1.28 & 1.31 & 1.25 & 1.27 \\
\hline
\end{tabular}

*Essential Amino Acids. ${ }^{1}$ Values are mean of duplicate determinations $\pm \mathrm{SE}$.

\section{Discussion}

African Yam Bean (AYB) used for diet formulation in this study was subjected to two different processing methods to remove the antinutrients present. Results showed that food consumption by fish throughout the experiment was good. A mean striking time of $0.7 \pm 0.1$ showed no difference in feed acceptability of diets with different dietary inclusion levels of AYB processed using the two methods of boiling and fermentation. This could be due to the presence of flavonoids which enhanced the palatability of the diets irrespective of the presence of alkaloids. Johnson (2001) reported that flavonoids are a large and complex group of phenolic compounds that contribute to the flavour and colour of vegetables and fruits, and account for most of the dissolved solids in beverages such as tea, coffee and wine.

Fermenting process improved crude protein and fat content of AYB while boiling decreased the crude protein and fat content. This is contrary to the report of Ogunji et al. (2008b) that most proteins of plant origin are nutritionally improved by heat treatment. Osuigwe et al. (2005) observed inferior performance of fish fed boiled Jack Beans Seed Meal (JBSM) relative to those fed the control diet. This was attributed to the effect of heat treatment which reduced the protein of JBSM by destroying some amino acids. Bressani et al. (1987) reported that heat treatment not only reduced the level of lysine but also destroyed methionine (both essential amino acids) in Jack Bean, thus reducing the biological value of JBSM protein.

Fish groups fed fermented yam bean at $45 \%$ level (FD2) performed better than the control. Reported values were not however, significantly different $(P>0.05)$. Specific growth rate (SGR) was higher $(3.3 \pm 0.2)$ compared to control $(3.2 \pm 0.4)$. Similarly PPV was $49.30 \pm 17.94$ and control $38.89 \pm 12.49$. At $40 \%$ of FAYB (FD1) the three dietary inclusions of boiled yam bean, values were not significantly different also. At $50 \%$ inclusion of $\mathrm{FAYB}$, fish performance was the poorest. Same poor performance was also observed with PPV. Commenting on the importance of different processing methods for legumes, Mubarak (2005) posits that cooking improves the protein quality by either destroying or inactivating heat labile anti-nutritional factors. Removal of undesirable components is essential for the enhancement and effective utilization of plant nutrients in animal feed (Ogunji et al., 2008b). This also may have influenced the improved protein composition of the fish carcass and haematological values above the control in this study (Table 7 and 8). Ates et al. (2008) report that decreases in erythrocyte, haemoglobin, and hematocrit values can be an indicator of anaemia with the subsequent result of 
Table 6: Growth performance of Clarias gariepinus fingerlings fed diets with fermented and boiled African yam bean at varying levels of incorporation $^{1}$

\begin{tabular}{|c|c|c|c|c|c|c|c|}
\hline & \multicolumn{3}{|c|}{ Fermented } & \multicolumn{3}{|c|}{ Boiled } & \multirow[b]{2}{*}{ Control } \\
\hline & $F_{1}$ & $F_{2}$ & $F_{3}$ & $\mathbf{B D}_{1}$ & $\mathbf{B D}_{2}$ & $\mathrm{BD}_{3}$ & \\
\hline Inclusion level & $40 \%$ & $45 \%$ & $50 \%$ & $40 \%$ & $45 \%$ & $50 \%$ & $0 \%$ \\
\hline Initial weight(g) & $1.38 \pm 0.00^{b}$ & $1.34 \pm 0.00^{\mathrm{a}}$ & $1.37 \pm 0.00^{\mathrm{ab}}$ & $1.37 \pm 0.01^{\mathrm{ab}}$ & $1.36 \pm 0.01^{\mathrm{ab}}$ & $1.37 \pm 0.01^{\mathrm{ab}}$ & $1.36 \pm 0.0^{\mathrm{ab}}$ \\
\hline Final weight $(\mathrm{g})$ & $6.02 \pm 0.65^{\mathrm{ab}}$ & $8.26 \pm 0.89^{b}$ & $4.40 \pm 1.34^{\mathrm{a}}$ & $5.06 \pm 1.22^{\mathrm{ab}}$ & $4.86 \pm 0.45^{\mathrm{ab}}$ & $6.96 \pm 0.62^{\mathrm{ab}}$ & $8.48 \pm 1.86^{b}$ \\
\hline Weight gain (g) & $4.63 \pm 0.65^{\mathrm{ab}}$ & $6.91 \pm 0.89^{b}$ & $3.03 \pm 1.34^{\mathrm{a}}$ & $3.69 \pm 1.20^{\mathrm{ab}}$ & $3.50 \pm 0.46^{\mathrm{ab}}$ & $5.59 \pm 0.62^{\mathrm{ab}}$ & $7.12 \pm 1.86^{\mathrm{b}}$ \\
\hline $\begin{array}{l}\text { Specific growth rate } \\
\left(\text { SGR \% day }{ }^{-1}\right)^{2}\end{array}$ & $2.61 \pm 0.19^{\mathrm{ab}}$ & $3.32 \pm 0.20^{\mathrm{a}}$ & $1.91 \pm 0.56^{\mathrm{b}}$ & $2.20 \pm 0.49^{b}$ & $2.26 \pm 0.17^{\mathrm{ab}}$ & $2.88 \pm 0.16^{\mathrm{ab}}$ & $3.17 \pm 0.44^{\mathrm{a}}$ \\
\hline $\begin{array}{l}\text { Protein production } \\
\text { value }(\mathrm{PPV})^{3}\end{array}$ & $42.70 \pm 3.23^{\mathrm{a}}$ & $49.30 \pm 17.94^{\mathrm{a}}$ & $19.43 \pm 12.51^{\mathrm{a}}$ & $47.63 \pm 9.55^{\mathrm{a}}$ & $49.36 \pm 11.49^{a}$ & $44.90 \pm 8.89^{a}$ & $38.89 \pm 12.49^{a}$ \\
\hline Percentage body & $335.91 \pm 47.89^{\mathrm{ab}}$ & $516.39 \pm 68.26^{a}$ & $220.72 \pm 97.37^{b}$ & $268.29 \pm 85.78^{\mathrm{ab}}$ & $258.96 \pm 36.71^{\mathrm{ab}}$ & $406.79 \pm 44.96^{\mathrm{ab}}$ & $524.12 \pm 138.99^{a}$ \\
\hline
\end{tabular}

weight gain (\%)

1. Values (mean $\pm \mathrm{SE}$ ) on the same horizontal line with different superscript letters are significantly different $(\mathrm{P}<0.05)$ from each other. $\mathrm{SE}$ is standard error.

2. $\mathrm{SGR}=\left(\mathrm{LnW}_{2}-\mathrm{LnW}_{1}\right) /\left(\mathrm{T}_{2}-\mathrm{T}_{1}\right) 100$

3. $P P V=100 \times[$ (crude protein final fish $\times$ biomass final tank weight) - (crude protein initial fish $\times$ biomass initial tank weight) $/$ (crude protein diet $\times$ total feed intake) 
Table 7: Proximate whole body composition (\% dry weight) of Clarias gariepinus fingerlings fed experimental $\operatorname{diets}^{1}(n=3)$

\begin{tabular}{|c|c|c|c|c|c|c|}
\hline $\begin{array}{c}\text { Dietary } \\
\text { treatment }\end{array}$ & $\begin{array}{c}\text { Crude } \\
\text { protein }\end{array}$ & Crude fat & Moisture & Dry matter & $\mathrm{NFE}^{2}$ & Energy $^{3} \mathrm{~kJ} / \mathrm{g}$ \\
\hline Initial carcass & $53.71 \pm 0.03^{c}$ & $6.28 \pm 0.01^{9}$ & $6.45 \pm 0.02 a$ & $93.55 \pm 0.02^{h}$ & $25.81 \pm 0.03^{d}$ & $19.21 \pm 0.07^{\mathrm{a}}$ \\
\hline FD1 & $54.64 \pm 0.03^{d}$ & $5.88 \pm 0.01^{\mathrm{e}}$ & $8.63 \pm 0.01^{\mathrm{e}}$ & $91.37 \pm 0.01^{d}$ & $24.76 \pm 0.03^{c}$ & $19.17 \pm 0.06^{\mathrm{a}}$ \\
\hline FD2 & $54.73 \pm 0.02^{d}$ & $5.77 \pm 0.01^{d}$ & $8.56 \pm 0.02^{d}$ & $91.45 \pm 0.02^{\mathrm{e}}$ & $24.69 \pm 0.03^{c}$ & $19.14 \pm 0.06^{\mathrm{a}}$ \\
\hline FD3 & $53.17 \pm 0.02^{b}$ & $5.41 \pm 0.01^{b}$ & $8.69 \pm 0.01^{f}$ & $91.31 \pm 0.01^{c}$ & $27.37 \pm 0.04^{f}$ & $18.90 \pm 0.08^{\mathrm{a}}$ \\
\hline BD1 & $55.93 \pm 0.02^{\mathrm{e}}$ & $6.02 \pm 0.01^{f}$ & $8.49 \pm 0.01^{c}$ & $91.51 \pm 0.01^{f}$ & $22.91 \pm 0.03^{b}$ & $19.34 \pm 0.05^{\mathrm{a}}$ \\
\hline BD2 & $57.82 \pm 0.02^{f}$ & $6.57 \pm 0.01^{h}$ & $8.28 \pm 0.03^{b}$ & $91.73 \pm 0.03^{9}$ & $19.80 \pm 0.02^{a}$ & $19.69 \pm 0.02^{\mathrm{a}}$ \\
\hline BD3 & $53.74 \pm 0.03^{c}$ & $5.57 \pm 0.01^{c}$ & $8.82 \pm 0.02^{g}$ & $91.18 \pm 0.02^{b}$ & $26.53 \pm 0.03^{e}$ & $19.01 \pm 0.07^{\mathrm{a}}$ \\
\hline Control & $52.79 \pm 0.07^{\mathrm{a}}$ & $4.41 \pm 0.01^{a}$ & $9.74 \pm 0.02^{h}$ & $90.26 \pm 0.02^{a}$ & $30.75 \pm 0.04^{\mathrm{g}}$ & $18.68 \pm 1.09^{\mathrm{a}}$ \\
\hline
\end{tabular}

${ }^{1}$ Values are mean of triplicate determination $\pm \mathrm{SE}$; Values on the same row with different superscript are significantly different from each other; ${ }^{2} \mathrm{NFE}=100-\left(\%\right.$ protein $+\%$ fat $+\%$ ash); ${ }^{3}$ Calculated by: crude protein $=23.9 \mathrm{~kJ} \mathrm{~g}^{-1}$, crude lipids $=39.8 \mathrm{~kJ} \mathrm{~g}^{-1}$ and NFE $=17.6 \mathrm{~kJ} \mathrm{~g}^{-1}$ (Schulz et al. 2005).

Table 8: Haematological parameters of Clarias gariepinus fingerling fed experimental diets*.

\begin{tabular}{lllll}
\hline Experimental diets & $\begin{array}{l}\text { PCV } \\
\left(\mathrm{gd} \mathrm{l}^{-1}\right)\end{array}$ & $\begin{array}{l}\text { HB } \\
(\%)\end{array}$ & WBC $\times\left(10^{3}\right.$ cells $\left.\mathrm{mm}^{-6}\right)$ & $\begin{array}{l}\text { RBC } \times\left(10^{3} \text { cells }\right. \\
\left.\mathrm{mm}^{-3}\right)\end{array}$ \\
\hline BD1 & $26.5 \pm 0.29^{\mathrm{e}}$ & $8.70 \pm 0.17^{\mathrm{e}}$ & $18.70 \pm 230.9^{\mathrm{f}}$ & $11.47 \pm 0.09^{\mathrm{e}}$ \\
BD2 & $24.0 \pm 0.00^{\mathrm{c}}$ & $8.07 \pm 0.03^{\mathrm{c}}$ & $17.70 \pm 57.7^{\mathrm{c}}$ & $11.17 \pm 0.03^{\mathrm{c}}$ \\
BD3 & $25.0 \pm 0.00^{\mathrm{d}}$ & $8.27 \pm 0.03^{\mathrm{cd}}$ & $18.15 \pm 28.9^{\mathrm{de}}$ & $11.27 \pm 0.03^{\mathrm{cd}}$ \\
FD1 & $27.5 \pm 0.29^{\mathrm{f}}$ & $9.17 \pm 0.03^{\mathrm{f}}$ & $19.15 \pm 28.9^{\mathrm{g}}$ & $11.70 \pm 0.06^{\mathrm{f}}$ \\
FD2 & $26.0 \pm 0.00^{\mathrm{e}}$ & $8.40 \pm 0.00^{\mathrm{d}}$ & $18.35 \pm 28.9^{\mathrm{ef}}$ & $11.40 \pm 0.06^{\mathrm{de}}$ \\
FD3 & $24.5 \pm 0.29^{\mathrm{cd}}$ & $8.17 \pm 0.15^{\mathrm{cd}}$ & $17.90 \pm 230.9^{\mathrm{cd}}$ & $11.27 \pm 0.09^{\mathrm{cd}}$ \\
Control & $21.5 \pm 0.29^{\mathrm{b}}$ & $7.27 \pm 0.03^{\mathrm{d}}$ & $15.35 \pm 28.9^{\mathrm{b}}$ & $8.47 \pm 0.03^{\mathrm{b}}$ \\
Initial & $14.5 \pm 0.29^{\mathrm{a}}$ & $4.87 \pm 0.09^{\mathrm{a}}$ & $10.45 \pm 28.9^{\mathrm{a}}$ & $5.77 \pm 0.03^{\mathrm{a}}$ \\
\hline
\end{tabular}

$*$ Values represent treatment mean \pm SE; Values on the same column with different superscript letters are significantly different $(\mathrm{P}<0.005)$ from each other. $\mathrm{PCV}=$ packed cell volume, $\mathrm{Hb}=$ haemoglobin, $\mathrm{WBC}=$ white blood cell count, $\mathrm{RBC}=$ Red blood cell count.

inhibition of erythropoiesis in the hemopoietic organism. Ogunji et al. (2007) also confirm that stressful conditions in fish and in mammals are associated with decreased growth, haematocrit (packed cell volume) and haemoglobin values. In this study, processing of African Yam Bean could have subdued the effect of the anti nutritional factors (stressor) and thus improved haematological values rather than bring about any decrease.

The high PPV values in all experimental groups except FD3 gave credibility to the effectiveness of the processing methods used in this study. Steffens (1989) confirmed that a higher value of PPV is indicative of good protein utilization. According to Machiels (1987) from the use of high quality protein of good digestibility and high level of dietary energy in the form of fats and or carbohydrate, PPV valves between 50 and 60 for the catfish, Clarias gariepinus could be obtained under favourable conditions. Based on PPV values and growth performance, it is observed that fermentation and boiling are good methods for processing African Yam Bean for Clarias gariepinus diets. However, inclusion level of fermented AYB in the African catfish diet should not exceed $45 \%$.

\section{Acknowledgement}

The authors are grateful to laboratory staff, family members and colleagues who supported us in different ways during the course of this study.

\section{References}

Asuzu, I. U. and Undie, A. (1986). Some observation on the toxic effects of the seed extract of Sphenostylis stenocarpa (Hochst ex A. Rider) Harms on intestinal muscle. Qual. Plant Food Hum. Nutr. 36, 3-9. 
Ates, B., Orun, I., Talas, S. Z., Durmaz, G. and Yilmaz, I. (2008). Effects of sodium selenite on some biochemical and hematological parameters of rainbow trout (Oncorhynchus mykiss Walbaum, 1792) exposed to $\mathrm{Pb}^{2+}$ and $\mathrm{Cu}^{2+}$. Fish. Physiol. Biochem. 34: 53-59.

Blaxhall, P. C. and Daibley, K. W. (1973). Routine hematology methods for use with fish blood. J ournal of fish Biology. 5: 771 - 781.

Bressani, R., Gomez, R. B., Garcia, A. and Elias, L. G. (1987). Chemical composition, amino acid content and protein quality of Canavalis spp seeds. J. Sci. Fd. Agric. 40:17-23

Eyo, J. E. and Ezechie, C. U. (2004). The effects of rubber (Harvea brasiliensis) seed meal based diets on diets acceptability and growth performance of Heterobranchus bidorsalis (male) x Clarias gariepinus (female) hybrid. Journal of sustainable Tropical Agricultural Research, 10: 20 - 25.

Fagbenro, O. A. and Jauncey, K. (1995). Growth and protein utilization by juvenile catfish (Clarias gariepinus) fed dry diets containing co-dried lactic acid -fermented fish silage and protein feedstuffs. Bio-resources Technology, 51: 29 - 35.

Jackson, A. J., Copper, B. S. and Matty, A. J. (1982). Evaluation of some plant proteins in complete diets for the tilapia. (Sarotherodon mossambicus). Aquaculture, 27: 97 - 109.

Bamidgeh 53 (1), 34 - 43.

Ogunji, J. O., Nimptsch, J., Wiegand, C. and Schulz, C. (2007). Evaluation of the influence of housefly maggot meal (magmeal) diets on catalase, glutathione S-transferase and glycogen concentration in the liver of Oreochromis niloticus fingerling. Comparative Biochemistry and Physiology, Part A 147: 942947

Ogunji, J. O., Kloas, W., Wirth, M., Schulz, C. and Rennert, B. (2008a). Housefly maggot meal (magmeal) as a protein source for Oreochromis niloticus (Linn.) Asian Fisheries Science, 21: 319-331.

Ogunji, J. O., Osuigwe, D. I., Okogwu, O. and Uwadegwu, N. (2008b). Response of African
Johnson, I. T. (2001). Mechanical and anticacinogenic effect of diet-related apoptosis in the intestinal mucosa. Institute of food research, Norwish Research park, Colney, Norwish NR4 7UA, UK14, 229-256.

Machiels, M. A. M. (1987). A dynamic simulation model for growth of African catfish Clarias gariepinus (Burchell 1822). IV The effect of feed formulation on the growth and feed utilization. Aquaculture 64: $505-323$.

Mubarak, A. E. (2005). Nutritional composition and antinutritional factors of mung bean seeds (Phaseolus aureus) as affected by some home traditional processes. Food Chem. 89: 489-495.

Obatolu, A. V., Fasoyiro, B. S. and Ogunsumi, L. (2001). Effect of processing on functional properties of yambean (Sphenostylis Stenocarpa). Food Sci. Technol, Res., 7 (4); 319-322.

Ogunji, J. O. (2004). Alternative protein sources in diets for farmed tilapia. Animalscience.com Reviews (2004) No. 13; CAB International Publishing (Oxford, UK). Nutrition Abstracts and Reviews: Series B 74 (8), 23N - 32N

Ogunji, J. O. and Wirth, M. (2001). Alternative protein sources as substitutes for fish meal in the diet of young tilapia Oreochromis niloticus (Linn). I sraeli Journal of Aquaculture. Bamidgeh

catfish, Clarias gariepinus (Burchell.), to diets of pigeon pea, Cajanus cajän, subjected to different processing methods. J. of the World Aquaculture Society. 39 (2): 215 - 224

Ogunji, J. O., Kloas, W., Wirth, M., Neumann, N. and Pietsch, C. (2008c). Effect of housefly maggot meal (magmeal) diets on the concentration of plasma glucose, cortisol and blood characteristics of Oreochromis niloticus fingerlings. Journal of Animal Physiology and Animal Nutrition 92: 511-518

Osuigwe, D. I., Obiekezie, A. I. and Onuoha, G. C., (2005). Some haematorlogical changes in hybrid catfish, Heterobranchus longifilis $x$ Clarias garipnus fed different dietary level of raw and boiled jackbean, Canavalia ensiforms 
seed meal. African Journal of Biotechnology 4 (9):1017-1021.

Schroeder, W. A., Kay, L. M. and Mills, R. S. (1990). Spectrophotometric analysis of amino acids using ninhydrin chemical reaction. Anal. Chem., 22: 760-760.

Schulz, C., Knaus, U., Wirth, M. and Rennert, B. (2005). Effects of varying dietary fatty acid profile on growth performance, fatty acid, body and tissue composition of juvenile pike perch (Sander lucioperca) Aquaculture Nutrition, 11, 1 - 11.

Singh, P., Maqsood, S., Samoon, M. H., Phulia, V., Danish, M. and Chalal, R. S. (2011). Exogenous supplementation of papain as growth promoter in diet of fingerlings of Cyprinus carpio. Int Aquat Res 3: 1 - 9.

Slawiski, H., Nagel, F., Wysujack, K., Balke, D.T., Franz, P. and Schulz, C. (2013). Total fishmeal replacement with canola protein isolate in diets fed to rainbow trout (Oncorhynchus mykiss W.) Aquaculture Nutrition 19: 535 - 542.

Sogbesan, O. A. and Ugwumba, A. A. A. (2006). Bionomics evaluation of garden snail (Limicolana aurora, Jay, 1937; Gastropoda: Limocalaria) meat meal in the diet of Clarias gariepinus fingerlings (Burchell, 1822). Nigerian J ournal of Fisheries, 2(3): 358 - 371.

Steffens, W. (1989). Principles of fish nutrition. pp. 21. Ellis Horwood Ltd, West Sussex, 108 pp

Tacon, A. G. J. and Jackson, A. J. (1985). Utilization of conventional and unconventional Aquaculture 103: 141-152 protein sources in practical fish feeds. In Nutrition and Feeding in Fish, Cowey, C.B., Mackie, A.M. and Bell, J.G., (eds). Academic press, London, pp. 119 - 145.

Tacon, A. G. J. and Metian, M. (2008). Global overview on the use of fish meal and fish oil in industrially compounded aquafeeds: trends and future prospects. Aquaculture, 285, 146-158.

Thorarinsdottir, R. I., Jokumsen, A., Bjornsson, B.T. and Torrissen, O. (2011). Local raw materials for production of fish feed for aquaculture. Nordic Innovation Centre Project no. $10102.64 p$. Islensk Matorka ehf. Iceland DTU-Aqua, Denmark Norwayhttp://www.nordicinnovation.org/Global / Publications/Reports/2011/2011_lokal raw m aterial fish feed rep.pdf. $\quad$ Retrieved $15 / 09 / 201 \overline{4}$

Uwaegbute, A. C., Ukegbu, P. O. and I kpeoha, A. (2012). Effect of Germination on Cooking, Nutrient Composition and Organoleptic Qualities of African Yam Bean (Sphenostylis stenocarpa). Journal of Biology, Agriculture and Healthcare. 2 (8), $28-32$.

Wedemeyer, G. A. and Yasutake, W. T. (1977). Clinical methods for the assessment of the effects of environmental stress on fish health. Technical papers of the US fish and wide life service No. 89. Washington, DC, US. Dept of the interior, fish and wild life service. Pp. 180

Webster, C. D. and Yancey, D. H. and Tidwell, J. H. (1992). Effect of partially or totally replacing fishmeal with soya bean meal on the growth of blue catfish (Ictalurus furcatus). 